\title{
Cryptic Regulation of Vasotocin Neuronal Activity but Not Anatomy by Sex Steroids and Social Stimuli in Opportunistic Desert Finches
}

\author{
David Kabelik Jenilee A. Morrison James L. Goodson \\ Department of Biology, Indiana University, Bloomington, Ind., USA
}

\section{Key Words}

Zebra finch • Bird - Vasotocin - Vasopressin - $c$-fos .

Testosterone $\cdot$ Estradiol $\cdot$ Seasonality $\cdot$ Bed nucleus of the stria terminalis $\cdot$ Lateral septum

\begin{abstract}
In most vertebrate species, the production of vasotocin (VT; non-mammals) and vasopressin (VP; mammals) in the medial bed nucleus of the stria terminalis (BSTm) waxes and wanes with seasonal reproductive state; however, opportunistically breeding species might need to maintain high levels of this behaviorally relevant neuropeptide year-round in anticipation of unpredictable breeding opportunities. We here provide support for this hypothesis and demonstrate that these neurons are instead regulated 'cryptically' via hormonal regulation of their activity levels, which may be rapidly modified to adjust VT signaling. First, we show that combined treatment of male and female zebra finches (Estrildidae: Taeniopygia guttata) with the androgen receptor antagonist flutamide and the aromatase inhibitor 1,4,6-androstatriene-3,17-dione does not alter the expression of VT immunoreactivity within the BSTm; however, both hormonal treatment and social housing environment (same-sex versus mixed-sex) alter VT colocalization with the immediate early gene product Fos (a proxy marker of neural activation) in the BSTm. In a second experiment, manipulations of estradiol (E2) levels with the aromatase inhibitor letrozole (LET) or
\end{abstract}

subcutaneous E2 implants failed to alter colocalization, suggesting that the colocalization effects in experiment 1 were solely androgenic. LET treatment also did not affect VT immunoreactivity in a manner reversible by E2 treatment. Finally, comparisons of VT immunoreactivity in breeding and nonbreeding individuals of several estrildid species demonstrate that year-round stability of VT immunoreactivity is found only in highly opportunistic species, and is therefore not essential to the maintenance of long-term pair bonds, which are ubiquitous in the Estrildidae.

Copyright $\odot 2010$ S. Karger AG, Basel

\section{Introduction}

Physiological mechanisms that underlie the expression of reproductive behaviors have been most extensively examined in vertebrate species that occupy predictable, seasonal habitats. In such species, sex hormone levels, numerous hormone-sensitive brain circuits, and behaviors associated with reproduction often fluctuate in a cyclical pattern that is tightly coupled to season [Marler et al., 2003; Wingfield, 2008; Hahn et al., 2009; Small and Moore, 2009]. One of the most dramatic examples is the arginine vasotocin/vasopressin (VT/VP) neuropeptide system that arises from neurons within the extended amygdala (specifically, the bed nucleus of the stria terminalis, BSTm) and projects to numerous areas of the basal

\section{KARGER}

๑ 2010 S. Karger AG, Basel

Fax +41613061234 E-Mail karger@karger.ch www.karger.com www.karger.com/bbe
David Kabelik

Department of Biology

Rhodes College

2000 N Parkway, Memphis, TN 38112 (USA)

Tel. +1 901843 3699, Fax +1 901843 3565, E-Mail kabelikd@ rhodes.edu 
forebrain, particularly the lateral septum (LS) [Buijs et al., 1986; Voorhuis et al., 1988; Crenshaw et al., 1992; Viglietti-Panzica et al., 1992; Wang and De Vries, 1993; reviews: De Vries and Panzica, 2006; Goodson, 2008; Boyd, 1994; Dubois-Dauphin et al., 1994; Lakhdar-Ghazal et al., 1995; Plumari et al., 2004; Kabelik et al., 2008]. Levels of VT and its mammalian homologue VP are highly dependent on circulating steroid hormone levels and thus often vary with hormonal changes across breeding season and photoperiod [e.g., Moore et al., 2000; Kabelik et al., 2008; Rasri et al., 2008; reviews: De Vries and Boyle, 1998; Goodson and Bass, 2001]. These seasonal changes might be relevant for numerous behaviors that are influenced by VT/VP, such as communication, pair bonding, aggression, social recognition, non-sexual affiliation, and parental behaviors [Goodson and Bass, 2001; Marler et al., 2003; De Vries and Panzica, 2006; Lim and Young, 2006; Caldwell et al., 2008; Veenema and Neumann, 2008].

In contrast to animals that occupy predictably seasonal habitats, animals that inhabit highly unpredictable environments must breed opportunistically following the onset of favorable conditions, which in the most extreme cases can occur at any time of the year [Skead, 1975; Perfito et al., 2007; Hahn and MacDougall-Shackleton, 2008; Hahn et al., 2009]. The zebra finch (Estrildidae: Taeniopygia guttata) is an excellent example from this extreme end of the continuum. Zebra finches are arid-adapted inhabitants of the Australian desert that initiate breeding following periods of rainfall, regardless of the time of year or current hormone levels [Zann, 1996; Cynx, 2001; Perfito et al., 2007]; however, the breeding response to rainfall is complex. Reproduction is timed such that the young hatch when the grasses begin to seed, and zebra finches flexibly modify their timing to match seasonal variation in the rate of grass growth. In winter, breeding might not occur until three months after drought-breaking rains, but notably, such long delays are observed only for the initiation of breeding after periods of non-permissive conditions. For most of the year, at least some pairs can be found breeding, and at these times the reproductive response to rainfall is immediate [Immelmann, 1965; Zann, 1996; Morton, 2009].

Given the importance of VT/VP for behaviors associated with breeding, we hypothesized that opportunistic species should be adapted to maintain a functional BSTm VT/VP system year-round, regardless of reproductive state or hormone levels. We therefore predicted that anatomical variables such as VT-immunoreactive (-ir) cell number, cell size, and the density of peptide within cells and fibers would remain constant following pharmaco- logical blockade of androgen receptors and inhibition of the enzyme aromatase (which is necessary to convert testosterone, T, to estradiol, E2). Furthermore, we hypothesized that hormonal state might nevertheless influence VT neuronal activity, but more 'cryptically' via regulation of baseline transcriptional activity, which would provide a means for rapid adjustments in VT neuronal function. Finally, we hypothesized that social factors (same-sex versus mixed-sex housing) would likewise influence VT neuronal activity, given that VP circuitry of the BSTm is influenced by the developmental social environment [Bester-Meredith and Marler, 2001; Frazier et al., 2006] and that VP mRNA increases in monogamous male prairie voles following cohabitation with a female [Wang et al., 1994].

To this end, we conducted two experiments. First, we treated male and female zebra finches with the androgen receptor antagonist flutamide (FLU) in conjunction with the aromatase inhibitor 1,4,6-androstatriene-3,17-dione (ATD) in order to assess the effects of inhibiting androgenic and estrogenic systems on VT neuroanatomy and baseline activity levels (as assessed by colocalization of VT neurons in the BSTm with the immediate early gene product Fos). Furthermore, the subjects were housed in either same-sex housing, or in mixed-sex housing with nests and nesting material in order to determine the effects of social environment on the VT system. Careful examination of female oviduct mass and hormone levels, however, revealed that the ATD treatment was not fully effective at preventing E2 production [cf. Soma et al., 1999]. Hence, we conducted a second experiment in which we treated male and female zebra finches (all in mixed-sex housing) with the aromatase inhibitor letrozole (LET) in order to impair estrogenic signaling, and we also examined the effects of E2 replacement.

These experiments were designed to determine whether the VT system of zebra finches shows adaptations to an unpredictable habitat. In considering the potential differences between zebra finches and other species in which VT/VP circuits have been examined, however, it is important to consider that they differ not only in their extreme opportunism, but also in their year-round maintenance of socially monogamous pair bonds, which are typically life-long [Zann, 1994, 1996]. Furthermore, unlike other species that have been examined, zebra finches also aggregate year-round in large groups that often number over 100 individuals [Zann, 1996]. Thus, given the importance of VT/VP for pair bonding in mammals and sociality in birds [Lim and Young, 2006; Carter et al., 2008; Donaldson and Young, 2009; Goodson and Kabe- 
lik, 2009], it might be the case that year-round stability in VT circuitry is an adaptation to either long-term pair bonding or extreme sociality, in addition to (or perhaps instead of) being an adaptation to an unpredictable environment.

Thus, in order to assess the relative importance of sociality and pair bond maintenance versus opportunism, we also conducted a third experiment in which we compared VT cell numbers in four species of estrildids during both reproductive and non-reproductive periods. All of the species maintain pair bonds year-round, but they differ in their degree of sociality. If VT stability is an adaptation to opportunistic breeding, but not pair bond maintenance or sociality, we predict that VT cell numbers will be similar across reproductive contexts in the more opportunistic species (zebra finch; violet-eared waxbill, Uraeginthus granatina; and Angolan blue waxbill, Uraeginthus angolensis; the latter two being African desert species), but not in the semi-opportunistic spice finch (Lonchura punctulata), an Indo-Asian species. Although spice finches are highly flexible in their breeding [Immelmann, 1965], they nonetheless exhibit pronounced endogenous rhythms of reproductive physiology that correlate with monsoon cyclicity and, unlike zebra finches, they exhibit photorefractoriness [Goodwin, 1982; Chaturvedi and Prasad, 1991; Sikdar et al., 1992; Hahn and MacDougall-Shackleton, 2008]. In contrast, if VT stability is an adaptation to sociality, then we expect to observe VT stability in the highly social zebra finch and spice finch, and perhaps in the modestly gregarious Angolan blue waxbill, but not in the territorial violet-eared waxbill, which occurs in male-female pairs year-round [Goodwin, 1982].

\section{Subjects and Methods}

\section{Subjects}

Domestic zebra finches and wild-caught spice finches were obtained from commercial suppliers. Waxbills were wild-caught in South Africa or lab-raised from wild-caught animals. Birds in all experiments were housed on a 14L:10D photoperiod with ad libitum access to finch mix and vitamin-enriched water. Subjects were treated humanely and in accordance with institutional and federal guidelines. Collections of wild birds were conducted under all applicable permits.

\section{Experiment 1: ATD+FLU}

Experimental Design and Manipulations. Twenty-seven individuals of each sex were used for this experiment, in which 15 males and 15 females were administered a single subcutaneous silastic implant containing ATD (Sigma-Aldrich, St. Louis, Mo., USA; i.d. $1.47 \mathrm{~mm}$, o.d. $1.96 \mathrm{~mm}$, total length $1.4 \mathrm{~cm}$, steroid pack- ing length of $1 \mathrm{~cm}$ ) and another implant containing FLU (SigmaAldrich; same dimensions and packing length as above). The remaining 12 males and 12 females were given two empty control (CTRL) implants. Within each sex, eight of the 15 ATD+FLU animals and seven of the 12 CTRL implant animals were housed in mixed-sex housing, and the remaining seven ATD+FLU and five CTRL animals were housed in same-sex conditions. Implants were checked daily. Four individuals were eliminated from analyses after losing implants (two same-sex males, one mixed-sex male, and one mixed-sex female, all ATD+FLU). One additional male (mixed-sex, CTRL) was eliminated due to illness.

After receiving implants, zebra finches were housed for three weeks in cages containing four individuals each (either same-sex or mixed-sex, as specified above). Two of the four animals in each cage were subjects and the remaining two were non-manipulated animals from our colony. Treatment assignments per cage were counterbalanced and mixed-sex groups contained an equal number of males and females. Cages were $46 \mathrm{~cm}$ wide $\times 46 \mathrm{~cm}$ high $\times 36 \mathrm{~cm}$ deep. Mixed-sex cage subjects were provided with plastic nesting cages and shredded burlap (nesting material). Any eggs laid were removed to prevent the onset of parental behaviors.

Most birds in the mixed-sex group were likely pair bonded, although individual pair bond assessments were not conducted. Single zebra finches are highly motivated to pair bond and pairs often form within minutes of introduction, both in the laboratory and in the field [Clayton, 1990; Kabelik et al., 2009]. Most single birds will pair within a few days, and importantly, pairing is not influenced by reproductive state. For instance, experimental mate removal in non-breeding, free-living zebra finches is followed by rapid re-pairing [Zann, 1996]. Thus, the present manipulations of endocrine state likely did not influence bonding. In addition, zebra finch partner preferences cannot be induced by exogenous VT [Goodson et al., 2004b] and normal pair bond formation in a colony setting is not impeded by chronic blockade of central $\mathrm{V}_{1}$-like receptors [Kabelik et al., 2009].

Three weeks after receiving implants, subjects were captured in the early morning, prior to lights-on (in order to ensure baseline Fos activity levels within the brain). The subjects were rapidly bled from the alar wing vein and euthanized with isoflurane. Subjects were transcardially perfused with $0.1 \mathrm{M}$ phosphate-buffered saline (PBS; pH 7.4), followed by $0.4 \%$ paraformaldehyde. Testes and ovaries were removed and weighed (we failed to obtain testes mass for one male). Brains were removed, postfixed overnight, and cryoprotected in 30\% sucrose in PBS for $48 \mathrm{~h}$ before sectioning on a cryostat.

Radioimmunoassay. Efficacy of implant treatment was verified by radioimmunoassay. Blood samples were centrifuged and plasma fractions were frozen at $-80^{\circ} \mathrm{C}$ until assayed. Plasma samples were assayed for $\mathrm{T}$ and $\mathrm{E} 2$ levels following methods adapted from Moore [1986]. Assays were run using T antibody from Wien Laboratories Inc (now Fitzgerald Industries International, Concord, Mass., USA) and E2 antibody from Biogenesis Ltd. (Poole, UK). Briefly, samples were equilibrated overnight with 2,000 cpm of radioactive hormone for determination of individual recoveries. Steroids were extracted from plasma using 30\% ethyl acetate in isooctane and separated by stepwise elution using celite chromatography. Collected fractions were dried down, resuspended in PBS, and assayed. Based on an average plasma volume of $55 \mu \mathrm{l}$, the minimum detectable values were $293 \mathrm{pg} / \mathrm{ml}$ for T and $81 \mathrm{pg} /$ $\mathrm{ml}$ for $\mathrm{E} 2$. 


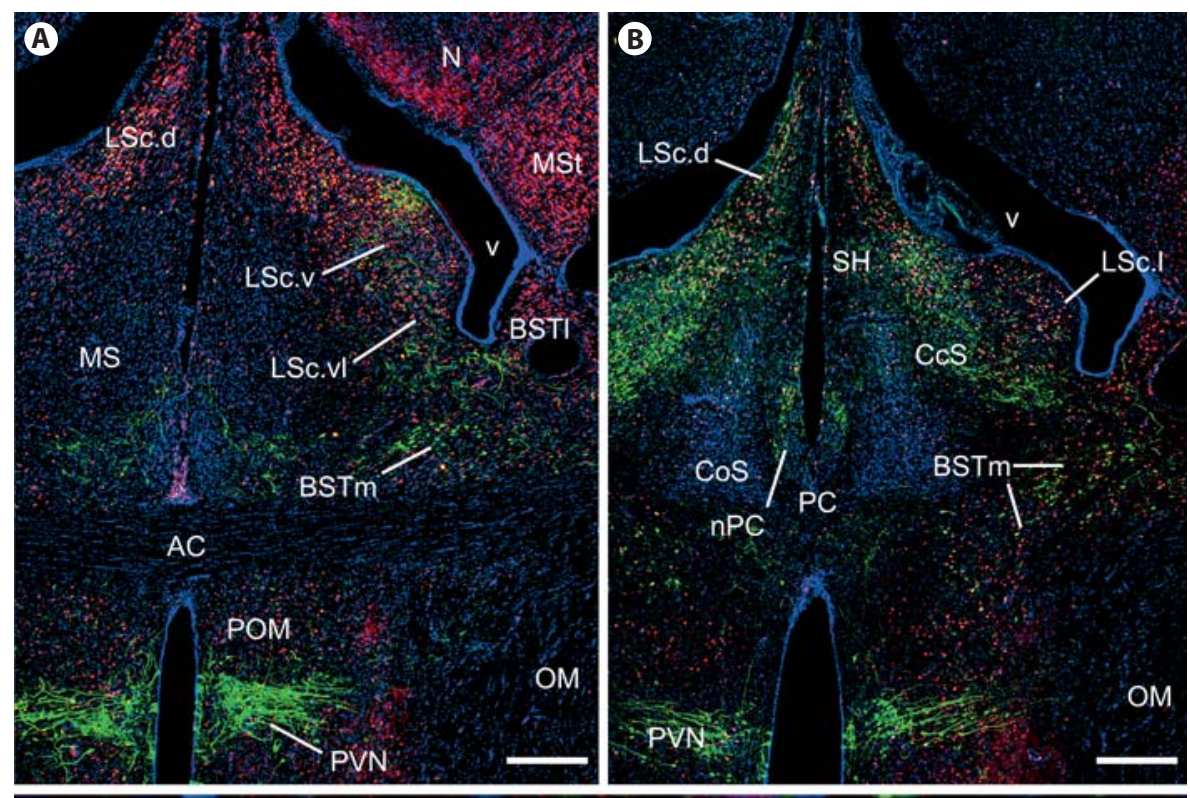

Fig. 1. Photomicrographs of VT-ir cells and fibers (Alexa Fluor 488; green), Fos-ir nuclei (Alexa Fluor 594; red), and DAPI nuclear stain (blue; for visualization of brain structure) in control-treated male zebra finches that had been housed with females in experiment 2 . The low-magnification images show the medial bed nucleus of the stria terminalis (BSTm) and lateral septum (LS) at the level of the anterior commissure (AC; $\mathbf{A}$ ) and just caudal to the commissure (B). Examples of VT-Fos colocalization are shown in panel $\mathbf{C}$. Abbrev.: BSTl, lateral bed nucleus of the stria terminalis; CcS, caudocentral septum; CoS, commissural septal nucleus; LSc, caudal division of the LS (d, dorsal zone; 1 ; lateral zone; v, ventral zone; vl, ventrolateral zone); MS, medial septum; MSt, medial striatum; $\mathrm{N}$, nidopallium; $\mathrm{nPC}$, nucleus of the pallial commissure; OM, occipitomesencephalic tract; PC, pallial commissure; POM, medial preoptic nucleus; PVN; paraventricular nucleus of the hypothalamus; $\mathrm{SH}$, septohippocampal septum; v, ventricle. Scale bars $=200 \mu \mathrm{m}$ in $\mathbf{A}$ and $\mathbf{B}$, and $20 \mu \mathrm{m}$ in $\mathbf{C}$.

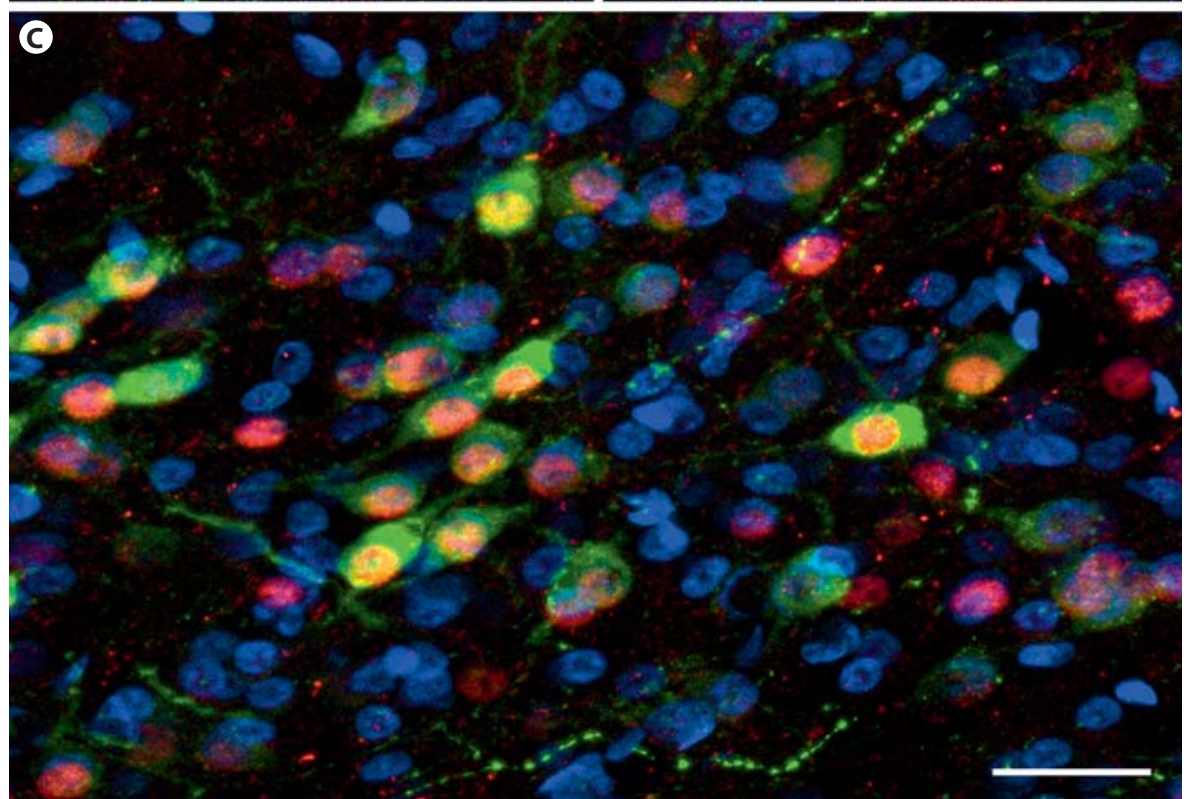

Immunocytochemistry. Brain tissue was cut on a cryostat into three series of $40-\mu \mathrm{m}$ free-floating sections, one of which was used in this study. Immunocytochemistry was performed according to standard procedures [e.g., Goodson et al., 2009b; Kabelik et al., 2010]. Tissue was rinsed $5 \times 10 \mathrm{~min}$ in PBS. This was followed by $20 \mathrm{~min}$ in $10 \mathrm{~mm}$ sodium citrate $\left(\mathrm{pH} 9.5\right.$; heated to $70^{\circ} \mathrm{C}$ in a water bath), which unmasks antigens, and then $1 \mathrm{~h}$ in PBS + $5 \%$ bovine serum albumin (BSA) $+0.3 \%$ Triton-X-100. Following this block step, sections were incubated for $40 \mathrm{~h}$ at $4{ }^{\circ} \mathrm{C}$ in guinea pig anti-VP (Bachem, Torrance, Calif., USA) and rabbit anti-Fos (Santa Cruz Biotechnology, Santa Cruz, Calif., USA), both at a concentration of $1 \mu \mathrm{g} / \mathrm{ml}$ in PBS $+2.5 \%$ BSA $+0.3 \%$ Triton-X-100. This was followed by $2 \times 30 \mathrm{~min}$ rinses in PBS; $1 \mathrm{hr}$ in a goat anti-guinea pig secondary conjugated to biotin $(8 \mu \mathrm{g} / \mathrm{ml}$; Vector
Laboratories, Burlingame, Calif., USA); $2 \times 15$ min rinses in PBS; $2 \mathrm{~h}$ in streptavidin conjugated to Alexa Fluor 488 ( $3 \mu \mathrm{g} / \mathrm{ml}$; Invitrogen, Carlsbad, Calif., USA) plus goat anti-rabbit secondary conjugated to Alexa Fluor $594(6 \mu \mathrm{g} / \mathrm{ml}$; custom cross-adsorbed against guinea pig IgG, Invitrogen) for $2 \mathrm{~h}$. All secondary steps were conducted at room temperature in $\mathrm{PBS}+2.5 \% \mathrm{BSA}+0.3 \%$ Triton-X-100. Following extensive rinsing in PBS, tissue was mounted on slides subbed with gelatin and chrome alum and coverslipped with ProLong Gold mounting medium containing DAPI nuclear stain (Invitrogen). Brains in this study were labeled in four runs, each containing a balance of groups and sexes.

Photomicroscopy and Data Analysis. The BSTm was photographed bilaterally above the anterior commissure, and at a level just caudal to the anterior commisure (fig. 1). We also captured 
images of the LS (a major target of VT projections from the BSTm) at middle and caudal levels. Monochrome images of each color channel were captured using a Zeiss AxioImager microscope (Carl Zeiss Inc., Göttingen, Germany) outfitted with a Z-drive and a Zeiss Apotome optical dissector (which yields focal plane resolution at near-confocal levels), a Zeiss Axiocam HRm camera and a high intensity X-Cite fluorescence illuminator (EXFO Photonic Solutions Inc., Mississauga, Ont., Canada). Images were captured in Zeiss AxioVision 4.6.3.0 and exported into Photoshop CS4 (Adobe Systems Inc., San Jose, Calif., USA). Data for all subjects were collected using standardized acquisition parameters.

Counts of VT-ir cells and VT-ir cells that were double-labeled for Fos were conducted blind to treatment and by a single observer. During the counting process, each cell was assigned a number using the 'count' feature in Photoshop. For optical density measurements of VT-ir neurons, we selected a subset of these cells (five per image; 20 total per subject) from the total number per section. Using Research Randomizer Form v.4.0 (www. randomizer.org), we randomly selected five of the numbered cells. Four subjects possessed fewer than 20 cells (10-18) and so all available cells were used for analysis. The mean optical density of the pixels comprising these cells was then obtained by outlining them using the 'lasso' tool, and noting the mean intensity level in the expanded histogram window. In order to quantify VTir fiber densities within the septum, circular 'area of interest' outlines (AOIs) were then placed in the caudocentral septum and in numerous LS subdivisions including the rostral division and the lateral, dorsal, ventral, and ventrolateral zones of the caudal division [see Goodson et al., 2004a]. A control AOI was also placed over the medial septum, which is devoid of VT fibers. The 'magic wand' tool was then used to choose the entire area within the AOI, and a mean intensity value was again recorded from the histogram window. The optical density of the medial septum was included as a covariate in all optical density analyses in order to control for variation in tissue autofluorescence. Higher optical density measures indicate higher levels of fluorescence.

In order to quantify treatment effects on hormone levels, VT cell number, percent colocalization, cell areas, and optical density measures, we used three-way (sex $\times$ implant type $\times$ housing condition) analyses of variance (ANOVAs). Separate two-way ANOVAs were used to determine the effects of implant type and housing condition on testes mass in males, and on oviduct mass in females. Testes and oviduct mass, hormone levels, and VT-ir cell counts and optical density measures were positively skewed and thus $\log _{10}$ transformed for analyses.

\section{Experiment 2: LET+E2}

The 18 male and 18 female zebra finches used in this study each received a subcutaneous implant plus three weeks of daily LET treatments (given orally). Six subjects of each sex were assigned to either: (1) CTRL group: an empty implant and $20 \mu \mathrm{l}$ daily of $0.9 \%$ saline vehicle; (2) LET group: an empty implant and $20 \mu \mathrm{l}$ daily of $10 \mathrm{mg} / \mathrm{ml}$ LET (Fisher Scientific, Pittsburgh, Pa., USA); or (3) LET+E2 group: an implant containing E2 (SigmaAldrich; i.d. $1.47 \mathrm{~mm}$, o.d. $1.96 \mathrm{~mm}$, total length $0.9 \mathrm{~cm}$, steroid packing length of $0.5 \mathrm{~cm}$ ) and $20 \mu \mathrm{l}$ daily of $10 \mathrm{mg} / \mathrm{ml} \mathrm{LET}$ (LET+E2). The LET or vehicle was administered with the lights off and only using a small flashlight, and by delivering the appropriate dose directly to the mouth using a micropipette.
In order to allow time for the collection of all subjects' brains following the same duration of treatment, we divided the subjects into six cohorts which were started and ended staggered by oneday intervals. The total duration of experimental treatment (21 days) was identical for each cage. One male and one female from each of the three treatment groups (six birds total) were given implants and housed together in each cage $(60 \mathrm{~cm}$ wide $\times 40 \mathrm{~cm}$ high $\times 36 \mathrm{~cm}$ deep). Four plastic nests and shredded burlap were provided in each cage, and all laid eggs were removed within a 24-hour period.

The $20 \mu$ l oral dose of LET was based on previous research on zebra finches [Lee et al., 2007]; however, because several birds became ill, we cut the LET and vehicle doses in half. This occurred approximately midway through the experiment, although the exact day of treatment varied across cages as not all cage groups began on the same day. Importantly, because each cage initially contained an equal number of subjects from each treatment group, this change in dosage was equal across all groups. In total, three LET+E2 females and one LET male died and another LET female was removed due to sickness.

Tissue collection, hormone assays, and photomicroscopy were conducted as above. Based on an average plasma volume of $113 \mu \mathrm{l}$, the minimum detectable hormone values were $24 \mathrm{pg} / \mathrm{ml}$ for $\mathrm{T}$ and $26 \mathrm{pg} / \mathrm{ml}$ for E2. Immunocytochemistry was conducted as above, except that donkey secondary antibodies were used and thus donkey serum was substituted (at double the concentration) for BSA and the immunocytochemistry was conducted across three counterbalanced runs. Statistical analyses were conducted as above except that housing treatment was not included because all subjects were in mixed-sex housing. Student's t post-hoc analyses were conducted with $\alpha=0.05$ as the significance level.

\section{Experiment 3: Estrildid Species Comparison}

Using tissue from four species of estrildids, we compared VTir cell numbers in the BSTm of animals that were sacrificed in reproductive condition and those that were sacrificed in non-reproductive condition. A total of 45 violet-eared waxbills (23 females, 22 males), 43 Angolan blue waxbills (21 females, 22 males), 25 spice finches (10 females, 15 males) and 27 zebra finches (16 females, 11 males) were used. All tissue for this study was processed in the course of previous experiments.

Animals in reproductive condition were collected as part of the experiments reported in Goodson and Wang [2006]. Territorial species were maintained as pairs in cages $100 \mathrm{~cm}$ wide $\times$ $43 \mathrm{~cm}$ high $\times 36 \mathrm{~cm}$ deep. Gregarious species were housed in mixed-sex groups of 6-8 individuals in cages $133 \mathrm{~cm}$ wide $\times 43$ $\mathrm{cm}$ high $\times 36 \mathrm{~cm}$ deep. Spice finches were wild-caught and maintained in captivity for a minimum of four months prior to experimentation. For the remaining three species, we used a mixture of wild-caught individuals that had been maintained in captivity for at least three years, and individuals that were raised in captivity from wild stock. All birds were provided with nests, nest material, dietary supplements (e.g., high-protein insectivore diets and mealworms), and bath water for at least six weeks prior to sacrifice. Only animals that built nests were used. None of the subjects were allowed to hatch young, and all eggs were removed four days prior to sacrifice. Wild-caught species were sacrificed during a time period that falls within the range of peak breeding [Goodson and Wang, 2006]. The reproductive status of all birds was verified by examination of gonads. 
Table 1. Oviduct or testes mass, plasma testosterone (T) level, and plasma estradiol (E2) level ( \pm SEM) for male and female zebra finches from either mixed-sex or same-sex housing

\begin{tabular}{|c|c|c|c|c|c|c|c|c|}
\hline & \multicolumn{4}{|l|}{ Females } & \multicolumn{4}{|l|}{ Males } \\
\hline & \multicolumn{2}{|l|}{ Mixed-sex } & \multicolumn{2}{|l|}{ Same-sex } & \multicolumn{2}{|l|}{ Mixed-sex } & \multicolumn{2}{|l|}{ Same-sex } \\
\hline & CTRL & $\mathrm{ATD}+\mathrm{FLU}$ & CTRL & $\mathrm{ATD}+\mathrm{FLU}$ & CTRL & $\mathrm{ATD}+\mathrm{FLU}$ & CTRL & $\mathrm{ATD}+\mathrm{FLU}$ \\
\hline $\mathrm{N}$ & 7 & 7 & 5 & 7 & 6 & 7 & $4-5$ & 5 \\
\hline Oviduct or testes mass, $\mathrm{g}$ & $0.22(0.11)$ & $0.17(0.10)$ & $0.05(0.02)$ & $0.02(0.005)$ & $0.04(0.003)$ & $0.06(0.004)$ & $0.05(0.002)$ & $0.06(0.008)$ \\
\hline $\mathrm{T}, \mathrm{ng} / \mathrm{ml}$ & $0.43(0.10)$ & $0.46(0.05)$ & $0.46(0.15)$ & $1.34(0.58)$ & $1.24(0.31)$ & $2.78(0.63)$ & $1.18(0.41)$ & $3.03(0.52)$ \\
\hline $\mathrm{E} 2, \mathrm{ng} / \mathrm{ml}$ & $0.18(0.04)$ & $0.19(0.06)$ & $0.13(0.04)$ & $0.18(0.04)$ & $0.10(0.02)$ & $0.15(0.04)$ & $0.10(0.02)$ & $0.14(0.04)$ \\
\hline
\end{tabular}

Subjects were given subcutaneous implants that were either empty (CTRL) or filled with 1,4,6-androstatriene-3,17-dione in combination with flutamide $(\mathrm{ATD}+\mathrm{FLU})$ for three weeks. $\mathrm{n}=$ group size.

Testes mass: CTRL versus ATD+FLU, $p=0.038$. Oviduct mass: mixed-sex versus same-sex, $p=0.039$. T level: males vs. females, $p<0.0001$. T level: ATD+FLU versus CTRL, $\mathrm{p}=0.0005$.

Animals in non-reproductive condition were collected as part of the experiment described in Goodson et al. [2005b], and although labeling of VT is not described in that report, the immunocytochemical methods closely follow those in experiment 1. Wild-caught species (same as above) were maintained in captivity for a minimum of four months prior to experimentation and were sacrificed at a time of year that typically falls outside the range of their peak breeding period [Goodson et al., 2005b]. All birds were housed in same-sex cages: $61-100 \mathrm{~cm}$ wide $\times 43 \mathrm{~cm}$ high $\times 36 \mathrm{~cm}$ deep. Territorial subjects were housed singly and gregarious subjects were housed in groups of 4-6 individuals.

Although subjects were collected in the context of two separate studies, the data appear to be highly comparable (e.g., virtually identical cell counts were obtained across conditions for the three most opportunistic species; see Results). Furthermore, all immunocytochemical batches were conducted using a mixture of species and sexes, and thus no species-specific effects can be attributed to variations across runs. This is important as we observed a seasonal change only in one species, the spice finch. Hence, this result cannot be due to separately running reproductive and nonreproductive tissues.

In contrast to the above experiments, VT-ir cell numbers were quantified by direct observation at $62 \times$ with $10 \times$ eyepieces on a Zeiss Axioscop fluorescence microscope that was outfitted with a 50-watt mercury lamp. Cell counts reported for experiment 3 were conducted prior to the acquisition of the imaging system used for experiments 1 and 2 (which is a much more sensitive system), thus cell counts for experiment 3 cannot be directly compared to other experiments. Given that many animals had low numbers of VT-ir cells, counts were conducted on four sections rather than two. All counts were conducted blind to treatment group and by an individual observer. The same observer conducted counts for both reproductive and non-reproductive conditions. A three-way ANOVA with the main effects of species, sex, and reproductive state was used to analyze log-transformed counts. Post-hoc ANOVA analyses were conducted separately for each species.

\section{Results}

\section{Experiment 1: $A T D+F L U$}

To validate the efficacy of our ATD+FLU implants, we examined testes and oviduct mass, as well as circulating levels of T and E2. We expected the ATD+FLU treatment to increase testes mass and production of $\mathrm{T}$ due to negative feedback, while inhibiting oviduct development due to a lack of circulating E2. In line with this prediction, we found a stimulatory effect of ATD+FLU on testes mass, relative to $\operatorname{CTRL}(\mathrm{F}(1,18)=5.03, \mathrm{p}=0.038$; table 1$)$. Oviduct mass was however responsive only to housing condition $(\mathrm{F}(1,22)=4.84, \mathrm{p}=0.039$; table 1$)$, with females in mixed-sex housing having larger oviducts than females in same-sex housing, regardless of implant treatment. This result suggests that E2 levels were not fully suppressed by ATD treatment, allowing E2 to stimulate oviduct development in mixed-sex females. These results suggest that only the FLU treatment was fully effective (also see RIA results in the next paragraph) and that treatment effects most likely reflect androgenic rather than estrogenic manipulations. No effect of housing condition on testes mass was observed in males, and no effect of implant type on oviduct mass was observed in females ( $p>0.05$ for all).

Males had higher $\mathrm{T}$ levels than females $(\mathrm{F}(1,41)=$ 31.31, $\mathrm{p}<0.0001$; table 1) and, as predicted, ATD+FLU treatment caused an increase in circulating $\mathrm{T}$ levels relative to CTRL subjects $(\mathrm{F}(1,41)=14.44, \mathrm{p}=0.0005$; table 1). No variables significantly affected E2 levels ( $p>$ 0.05 for all); it is important to note that E2 levels were not suppressed in either ATD+FLU males or females, further 


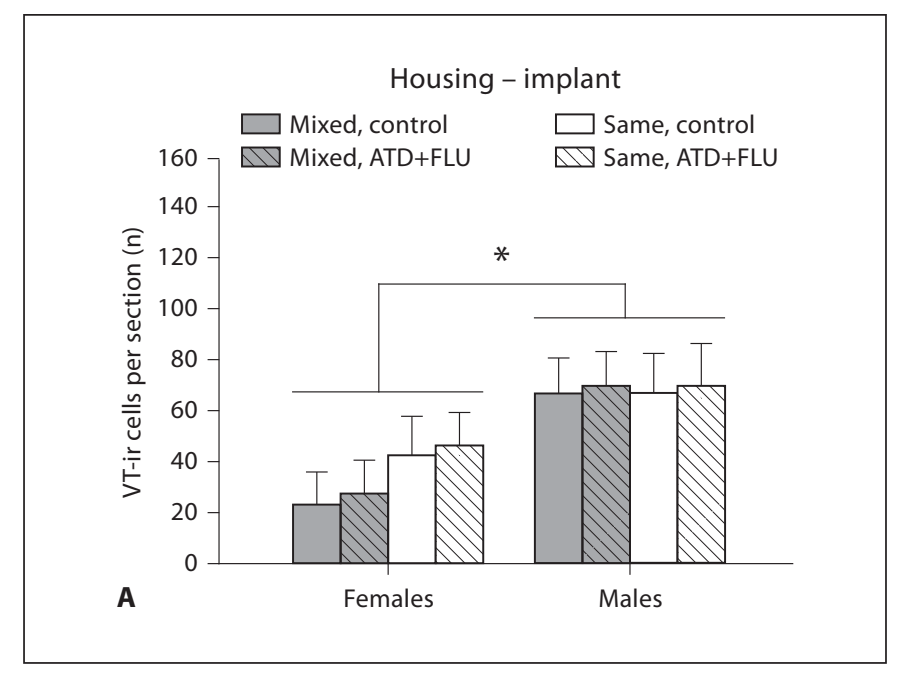

Fig. 2. Vasotocin-immunoreactive (VT-ir) cell numbers in the medial bed nucleus of the stria terminalis (BSTm) are male-biased but not altered by social and hormonal manipulations in the opportunistically breeding zebra finch. (A) Experiment 1: Males possessed more VT-ir neurons than did females $(\mathrm{p}=0.002)$; however, combined treatment with the aromatase inhibitor 1,4,6-androstatriene-3,17-dione and the androgen receptor antagonist flutamide (ATD+FLU) did not alter VT-ir cell numbers from the mean exhibited by control (CTRL) subjects $(\mathrm{p}=0.62)$. Cell numbers were likewise unaltered by social housing environment (same-sex versus mixed-sex; $\mathrm{p}=0.15$ ). Note that ATD was not fully effective at blocking E2 production, and thus the ATD+FLU

underscoring the conclusion that ATD was ineffective at fully suppressing E2 production.

VT-ir cell number was sexually dimorphic and malebiased $(\mathrm{F}(1,41)=11.09, \mathrm{p}=0.002)$, but neither implant type $(\mathrm{F}(1,41)=0.25, \mathrm{p}=0.62)$, nor housing condition $(\mathrm{F}(1,41)=2.19, \mathrm{p}=0.15)$ were related to VT-ir cell number (fig. 2A). No interactions among sex, implant type, or housing condition were present ( $p>0.05$ for all). Likewise, males possessed more immunoreactivity within VT neurons, as assessed by higher optical density measurements, than did females $(F(1,40)=12.68, \mathrm{p}=0.001$; males: $11.62 \pm 0.79$, females: $8.73 \pm 0.61$, arbitrary units). Again, no effects of implant type $(\mathrm{F}(1,40)=0.28, \mathrm{p}=0.60)$, housing condition $(\mathrm{F}(1,40)=0.14, \mathrm{p}=0.71)$, or any interaction ( $p>0.05$ for all) were observed. Finally, no effects of sex, implant type, housing type, or any interactions were present for VT cell area measurements or optical density measurements of septal VT fibers ( $p>0.05$ for all; data not shown).

For combined levels of the BSTm, VT-Fos colocalization was significantly higher under mixed-sex housing conditions $(\mathrm{F}(1,41)=15.20, \mathrm{p}=0.0004)$, but it was not

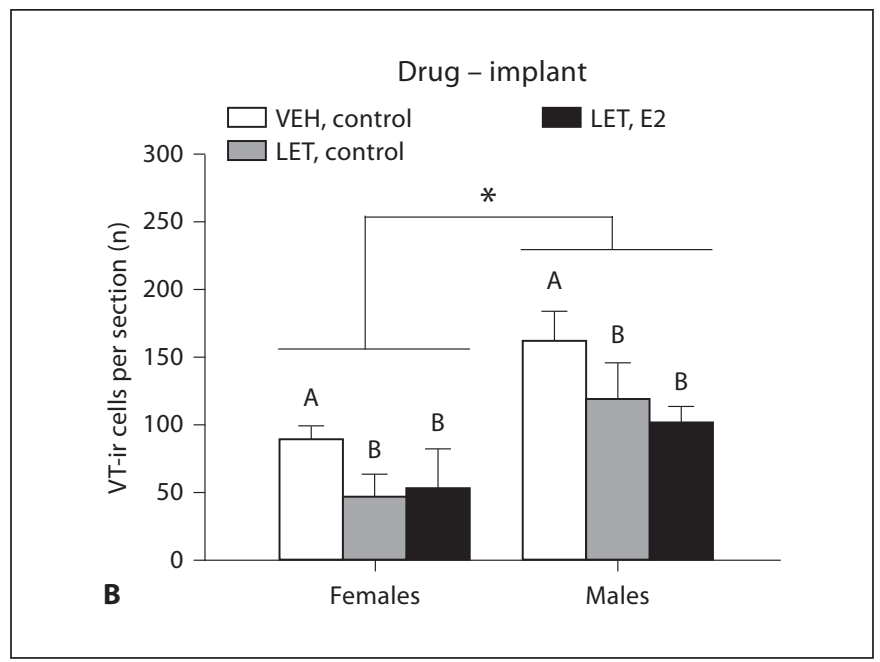

treatment was only successful at blocking androgen receptors. (B) Experiment 2: Males again expressed more VT-ir neurons than did females ( $p=0.0005)$. In this experiment, letrozole (LET) was successfully used to block E2 production, and hormonal treatments did alter VT-ir neuron counts ( $\mathrm{p}=0.03)$; however, cell numbers in CTRL subjects were very high (cf. A) and the effects of LET treatment could not be prevented by simultaneous administration of E2 (LET+E2), indicating that no treatment effects can be attributed to E2 manipulations. * Denotes groups differing at $\mathrm{p}<0.05$ for main effect of sex. Different letters above bars denote groups differing at $\mathrm{p}<0.05$ for main effect of drug and implant type. Data are shown as means \pm SEM.

significantly affected by ATD+FLU treatments $(\mathrm{F}(1,41)=$ $3.40, \mathrm{p}=0.072)$. Likewise, no effect of $\operatorname{sex}(\mathrm{F}(1,41)=0.88$, $\mathrm{p}=0.35$ ), nor any interactions ( $\mathrm{p}>0.05$ for all) were present. Because functional differences between the two BSTm levels have previously been observed [Meddle et al., 1999; Goodson and Evans, 2004; Goodson et al., 2005a; Kabelik et al., 2010], we also conducted separate analyses for the rostral and caudal BSTm. Whereas the effects of both housing condition $(\mathrm{F}(1,41)=11.34$, $\mathrm{p}=$ $0.002)$ and implant type $(F(1,41)=7.36, p=0.01)$ were highly significant at the rostral (supracommissural) level of the BSTm, only housing condition $(\mathrm{F}(1,41)=13.40$, $\mathrm{p}=0.0007)$ and not hormonal treatment $(\mathrm{F}(1,41)=1.07$, $\mathrm{p}=0.31$ ) was significant at the caudal level (fig. 3).

\section{Experiment 2: $L E T+E 2$}

To validate the efficacy of our LET and LET+E2 treatments, we again examined testes and oviduct mass, as well as circulating levels of T and E2 (table 2). The treatments were found to affect both testes $(\mathrm{F}(2,14)=41.11$, $\mathrm{p}<0.0001)$ and oviduct mass $(\mathrm{F}(2,11)=30.01, \mathrm{p}<0.0001)$. Post-hoc analyses revealed that the LET treatment alone 


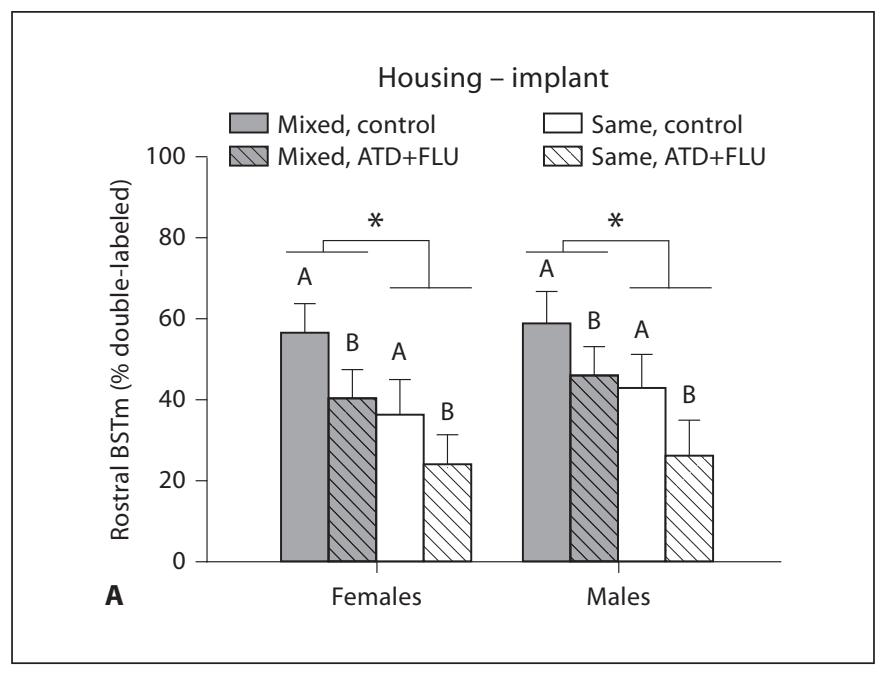

Fig. 3. Both social environment and androgen levels cryptically regulate VT-ir neurons in the BSTm of the opportunistically breeding zebra finch. VT-Fos colocalization was greater in subjects from mixed-sex groups than subjects from same-sex housing, both at rostral $(\mathbf{A} ; \mathrm{p}=0.002)$, and caudal $(\mathbf{B} ; \mathrm{p}=0.0007)$ levels of the BSTm. CTRL subjects likewise exhibited higher colocaliza-

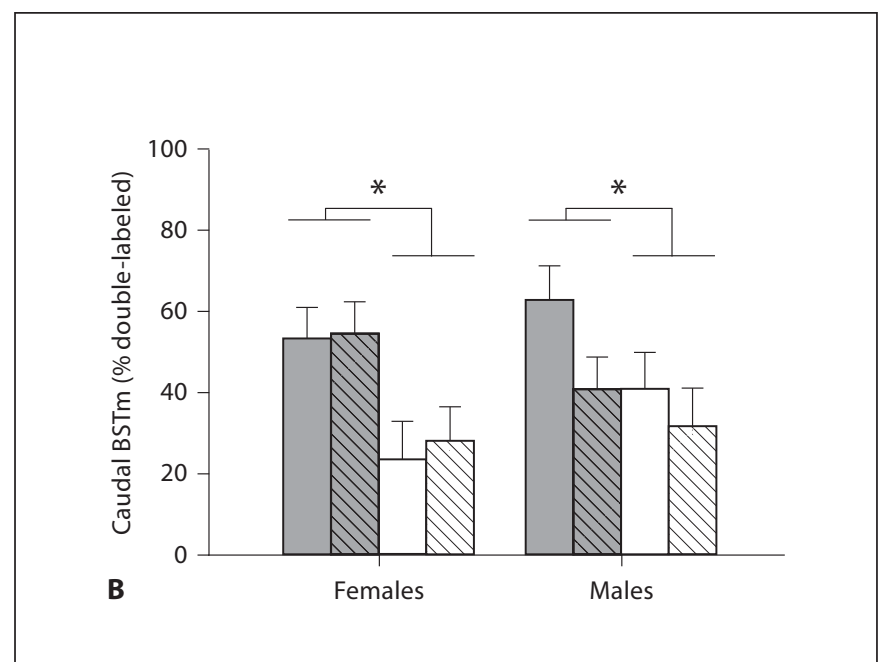

tion rates than ATD+FLU subjects, although solely at the rostral $(\mathbf{A} ; \mathrm{p}=0.01)$ and not caudal $(\mathbf{B} ; \mathrm{p}=0.31)$ BSTm. Data are shown as means \pm SEM. ${ }^{*}$ Denotes groups differing at $\mathrm{p}<0.05$ for main effect of housing. Different letters above bars denote groups differing at $\mathrm{p}<0.05$ for main effect of implant type. See figure 2 for an explanation of treatment groups and other acronyms.

Table 2. Testes or oviduct mass, plasma testosterone (T) level, and plasma estradiol (E2) level ( \pm SEM) for male and female zebra finches from mixed-sex housing

\begin{tabular}{|c|c|c|c|c|c|c|}
\hline & \multicolumn{3}{|l|}{ Females } & \multicolumn{3}{|l|}{ Males } \\
\hline & CTRL & LET & $\mathrm{LET}+\mathrm{E} 2$ & CTRL & LET & $\mathrm{LET}+\mathrm{E} 2$ \\
\hline $\mathrm{N}$ & 6 & 5 & 3 & 6 & 5 & 6 \\
\hline Testes or oviduct mass, $\mathrm{g}$ & $0.073(0.024)$ & $0.023(0.006)$ & $0.43(0.08)$ & $0.048(0.006)$ & $0.042(0.005)$ & $0.003(0.001)$ \\
\hline $\mathrm{T}, \mathrm{ng} / \mathrm{ml}$ & $0.033(0.006)$ & $0.28(0.040)$ & $0.016(0.007)$ & $3.47(0.67)$ & $3.84(0.95)$ & $0.023(0.004)$ \\
\hline $\mathrm{E} 2, \mathrm{ng} / \mathrm{ml}$ & $0.023(0.003)$ & $0.030(0.004)$ & $1.82(0.14)$ & $0.033(0.005)$ & $0.052(0.010)$ & $0.99(0.21)$ \\
\hline
\end{tabular}

Subjects were orally treated with vehicle or letrozole on a daily basis for three weeks. Subjects were also given subcutaneous implants that were either empty or filled with crystalline E2 for the duration of the study. CTRL $=$ vehicle plus empty implant, LET $=$ letrozole plus empty implant, LET+E2 = letrozole plus E2; $\mathrm{N}$ = group size.

Testes mass, $\mathrm{p}<0.0001$. Oviduct mass, $\mathrm{p}<0.0001$. T level, males vs. females, $\mathrm{p}<0.0001$.

T level, treatment effect, $\mathrm{p}<0.0001$; posthoc: $\mathrm{LET}>\mathrm{CTRL}>\mathrm{LET}+\mathrm{E} 2$.

T level, sex $\times$ treatment, $\mathrm{p}<0.0001$; posthoc: $\delta$ LET $=\delta \mathrm{CTRL}>$ \& $\mathrm{LET}>$ $+\mathrm{CTRL}=\delta \mathrm{LET}+\mathrm{E} 2=q \mathrm{LET}+\mathrm{E} 2$.

E2 level, treatment effect, $\mathrm{p}<0.0001$; posthoc: $\mathrm{LET}+\mathrm{E} 2>\mathrm{CTRL}=\mathrm{LET}$.

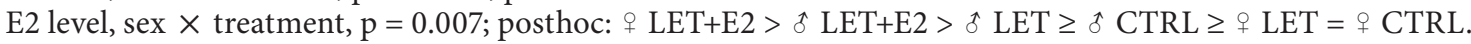

did not impact testes mass relative to that in CTRL males, but LET+E2 caused significant testicular regression, likely due to inhibitory negative feedback. In females, the oviduct mass of LET females was less than a third of that of CTRL females, but these groups did not differ significantly in post-hoc analyses, possibly due to a floor effect as both groups had extremely small oviducts. Post-hoc analyses did reveal, however, that LET+E2 treatment significantly increased oviduct size relative to both LET and CTRL females.

Both $\mathrm{T}$ and $\mathrm{E} 2$ differed significantly among treatment groups (table 2). $\mathrm{T}$ was found to be higher in males than 


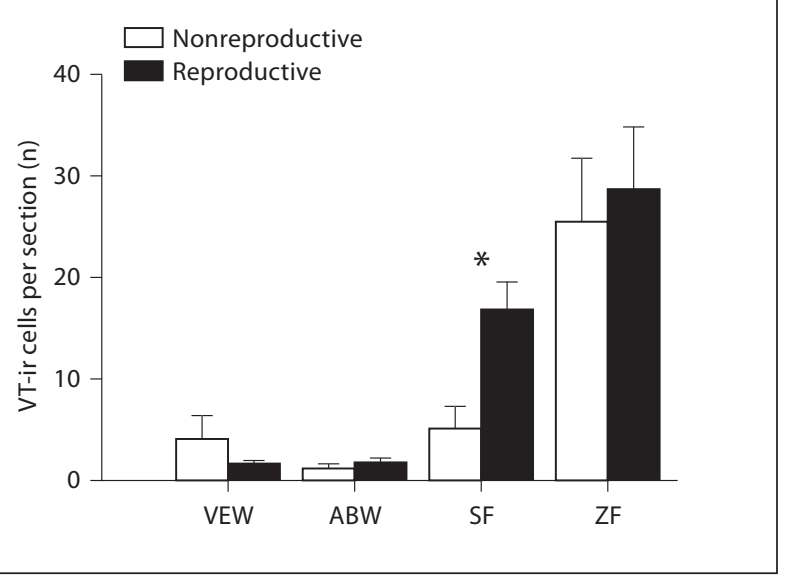

Fig. 4. VT-ir cell number in the BSTm does not vary with reproductive condition in highly opportunistic species of estrildids (territorial violet-eared waxbill, VEW; modestly gregarious Angolan blue waxbill, ABW; highly gregarious zebra finch, ZF; p > 0.05 for all), but does vary with condition in the highly gregarious spice finch (SF) a semi-opportunistic species that exhibits endogenous cycles of reproductive physiology that are closely tied to the monsoon season $\left({ }^{*} \mathrm{p}=0.001\right)$. All four species exhibit year-round maintenance of socially monogamous pair bonds. Sex differences were very modest and species-specific (see Results), thus sexes are shown pooled. Post-hoc analyses revealed that the two highly gregarious species exhibit significantly more VT-ir neurons than do the less gregarious species $(\mathrm{p}<0.05)$. Data are shown as means \pm SEM.

in females $(\mathrm{F}(1,25)=202.79, \mathrm{p}<0.0001)$, and also to differ with hormonal treatment $(\mathrm{F}(2,25)=162.40, \mathrm{p}<$ 0.0001). Post-hoc analyses revealed that LET subjects had higher T levels than CTRL subjects, and CTRL subjects had higher T levels than LET+E2 individuals. A significant sex $\times$ treatment effect $(\mathrm{F}(2,25)=52.93, \mathrm{p}<0.0001)$ helps to explain these data, demonstrating that in females, LET subjects have higher T levels than CTRL and LET+E2 subjects; whereas in males, both CTRL and LET subjects have higher T levels than LET+E2 subjects. E2 was also found to vary with treatment $(\mathrm{F}(2,25)=242.63$, $\mathrm{p}<0.0001)$, although not with sex $(\mathrm{F}(1,25)=0.001, \mathrm{p}=$ 0.97). Post-hoc analyses revealed that LET+E2 subjects had higher E2 levels than both CTRL and LET subjects. A significant sex $\times$ treatment effect was also present for $\mathrm{E} 2(\mathrm{~F}(2,25)=6.03, \mathrm{p}=0.007)$, although this only reflects a sex difference in the magnitude of treatment effects, such that LET+E2 produced a greater elevation of E2 in females than in males.

Overall, these results demonstrate that the LET treatment was effective because it prevented conversion of $\mathrm{T}$ to $\mathrm{E} 2$, thereby causing an increase in T levels, while also maintaining minimal E2 levels and oviduct masses. The E2 implant treatment was also effective as it significantly increased E2 levels in both sexes, as well as oviduct mass.

As in the first experiment, VT-ir cell number was found to be sexually dimorphic and male-biased $(\mathrm{F}(1,25)=16.29, \mathrm{p}=0.0005$; fig. $2 \mathrm{~B})$. Furthermore, a significant effect of treatment was detected $(\mathrm{F}(2,25)=4.05$, $p=0.03$ ), but post-hoc analyses demonstrate that both the LET and LET+E2 groups had fewer VT-ir neurons than did the CTRL group. Optical density measurements were again higher in males than in females $(\mathrm{F}(1,24)=5.57, \mathrm{p}=$ 0.03 ; males: $36.39 \pm 1.97$, females: $29.06 \pm 1.64$, arbitrary units, brighter capture settings than in experiment 1 resulted in higher values), with no effect of treatment or interaction present ( $p>0.05$ for all; data not shown). No effects of treatment were observed on VT cell area or septal VT optical density measurements ( $p>0.05$ for all; data not shown). Furthermore, no effects of sex, treatment, or an interaction between the two were observed for VT-Fos colocalization ( $p>0.05$ for all), providing further support for the interpretation that the treatment effects on VT-Fos colocalization in Experiment 1 are attributable to blockade of androgen receptors. The colocalization values (mean \pm SEM) for CTRL, LET, and LET+E2 were $49.5 \pm 8.6,64.4 \pm 5.6$, and $46.1 \pm 4.7$ for females, and $60.6 \pm 8.7,54.2 \pm 9.4$, and $52.5 \pm 6.0$ for males.

\section{Experiment 3: Estrildid Species Comparison}

Analyses of VT-ir cell counts across all four species revealed significant effects of species $(\mathrm{F}(3,124)=43.07$, $\mathrm{p}<0.0001$; fig. 4) and $\operatorname{sex}(\mathrm{F}(1,124)=7.54, \mathrm{p}=0.007)$. In terms of the latter, males exhibited a modestly greater number of VT-ir cells in the BSTm than females across all species (10.7 \pm 1.46 SEM vs. $9.4 \pm 1.49)$. Post-hoc analyses involving individual species, however, revealed that only male violet-eared waxbills $(\mathrm{F}(1,41)=11.77, \mathrm{p}=0.0014)$ and spice finches possessed $(\mathrm{F}(1,21)=7.26, \mathrm{p}=0.014)$ significantly more VT-ir neurons than did females. No differences in VT-ir cell counts were observed in this study between male and female Angolan blue waxbills $(\mathrm{F}(1,39)=$ $0.49, \mathrm{p}=0.49)$ and zebra finches $(\mathrm{F}(1,23)=0.16, \mathrm{p}=0.69)$.

The main effect of reproductive state was not found to be significant $(\mathrm{F}(1,124)=3.70, \mathrm{p}=0.057)$, although the interaction of species $\times$ reproductive state was significant $(\mathrm{F}(3,124)=3.15, \mathrm{p}=0.027)$. No other interactions were found (all p >0.05). To examine the interaction effect more closely, we conducted post-hoc analyses of reproductive condition separately for each species. Only in spice finches was reproductive condition a significant de- 
terminant of VT-ir cell numbers $(\mathrm{F}(1,23)=14.82, \mathrm{p}=$ 0.0008 ), with reproductive individuals possessing more VT-ir cells in the BSTm than nonreproductive individuals. The other three species exhibited a convincing lack of similar trends: violet-eared waxbill $(\mathrm{F}(1,43)=1.06, \mathrm{p}=$ $0.31)$, Angolan blue waxbill $(\mathrm{F}(1,41)=0.0035, \mathrm{p}=0.95)$, zebra finch $(\mathrm{F}(1,25)=0.81, \mathrm{p}=0.38)$. Thus, cell number varied with reproductive condition only in the more seasonal species and not in the three highly opportunistic species.

\section{Discussion}

The present experiments demonstrate that in the opportunistically breeding zebra finch, VT circuitry of the BSTm and LS remains anatomically stable following both natural and experimental alterations of sex steroid hormones. In this respect the zebra finch is very different from laboratory rats and mice [De Vries et al., 1984, 1986; Miller et al., 1989; Scordalakes and Rissman, 2004] and species that exhibit seasonal patterns of breeding [Buijs et al., 1986; Voorhuis et al., 1988; Crenshaw et al., 1992; Viglietti-Panzica et al., 1992; Wang and De Vries, 1993; reviews: Boyd, 1994; Dubois-Dauphin et al., 1994; Lakhdar-Ghazal et al., 1995; Goodson and Bass, 2001; Plumari et al., 2004; De Vries and Panzica, 2006; Kabelik et al., 2008]. Despite this anatomical stability, however, the VT system of zebra finches is influenced somewhat cryptically by both social and hormonal variables, such that housing subjects in mixed-sex cages with nests increases Fos immunoreactivity within VT-ir neurons of the BSTm, whereas manipulations that block androgenic steroid circuits decrease VT-Fos colocalization. Blocking E2 production does not affect VT-Fos colocalization, suggesting that hormonal regulation of VT-ir neurons is primarily androgenic. We propose that this pattern of hormonal sensitivity in the zebra finch is an adaptation to opportunistic breeding, and support this hypothesis with comparative data on several estrildid species, as described in the second section below.

\section{Steroidal Regulation of VT/VP Circuitry}

VT/VP mRNA and peptide levels have been shown to be steroid-dependent in both rodents and galliform birds [Panzica et al., 2001; De Vries and Panzica, 2006]. In rats, castration virtually eliminates VP mRNA in the BSTm within a week and reduces stored peptide over weeks to months, whereas $\mathrm{T}$, acting primarily through estrogenic metabolites, can eventually restore VP levels [De Vries et al., 1984, 1985, 1986; van Leeuwen et al., 1985; Miller et al., 1989, 1992]. Although T treatment increases cytoplasmic mRNA after a matter of days in gonadectomized rats or hamsters kept on short photoperiods, full restoration of cytoplasmic peptide and axonal projections seems to require weeks [Szot and Dorsa, 1994; Rasri et al., 2008].

Such a gradual modulation of the VT/VP system might not be sufficiently rapid to modulate the necessary changes associated with the rapid initiation of breeding and related behaviors in opportunistically breeding species. Opportunistic species need to not only respond rapidly to stimuli associated with rainfall, such as the vegetation growth necessary for nest building and the provisioning of offspring [Skead, 1975; Zann, 1996], but they also need to remain flexible. In cases where rains are not prolonged, vegetation grows slightly and then wilts [Skead, 1975]. Hence, opportunistically breeding species need mechanisms that both allow for the rapid initiation of breeding after sufficient rainfall, as well as for continual regulation and flexibility, such that breeding-related changes in physiology and behavior can be halted or delayed if rains are insufficient.

The few experiments conducted to date in zebra finches have not convincingly determined whether steroidal regulation of the VT system in this highly opportunistic species differs from that of seasonal breeders. Kimura et al. [1999] showed that $\mathrm{T}$ treatment of female zebra finches can increase VT cell counts within the BSTm, but treatment levels were supraphysiological, producing circulating $\mathrm{T}$ levels three times that of control males. In contrast, Voorhuis and de Kloet [1992] found that T manipulations did not alter VT immunoreactivity, but their data were not reported quantitatively.

Our findings here, which are based on experimental antagonism of androgenic and estrogenic circuits in zebra finches, in addition to species comparisons of reproductive and nonreproductive individuals (see next section), support the hypothesis that under physiological conditions, VT circuitry in the BSTm is not regulated by gonadal steroids in opportunistically breeding species as it is in seasonally breeding species. As shown in experiment 1 , blockade of androgen receptors fails to alter the expression of VT-ir in the BSTm, although this manipulation does alter baseline levels of VT-Fos colocalization, providing a potentially more rapid mechanism for the regulation of reproductive behaviors. Mixed-sex housing with nesting material also increased VT-Fos colocalization over the levels of subjects from same-sex cages, independent of hormonal treatment. 
Unfortunately, ATD treatment in experiment 1 did not fully block E2 production [see Soma et al., 1999 for a similar finding in song sparrows, Melospiza melodia]. Hence, a second experiment was conducted using the aromatase inhibitor LET. The results of this second experiment were likewise less than straightforward, as subjects in both the LET and LET+E2 groups differed from CTRL subjects in VT-ir cell counts. But, because the LET and LET+E2 treatments had opposite effects on E2 levels, and VT-ir cell numbers were virtually identical in the LET and LET+E2 groups, we can conclude that any potential effects of LET treatment on VT-ir cell counts were clearly not attributable to E2 action.

Thus, the combined data from experiments 1 and 2 indicate that VT-ir cell number in the zebra finch BSTm is insensitive to sex steroids, but that VT-Fos colocalization is regulated via activation of androgen receptors. This stands in contrast to other vertebrates that have been examined, in which the steroidal control of BSTm VT/VP is primarily estrogenic, with or without a more modest androgenic contribution [De Vries et al., 1994; VigliettiPanzica et al., 2001; reviews: Goodson and Bass, 2001; De Vries and Panzica, 2006]. Other studies have focused on quantification of VT/VP mRNA or immunoreactivity, however, not on the expression of transcription factors such as Fos. Notably, a variety of hormone receptors are colocalized with VT/VP in the BSTm, including glucocorticoid, progestin, estrogen, and androgen receptors, with $90 \%$ of BSTm VP neurons expressing androgen receptors in rats [Axelson and Leeuwen, 1990; Zhou et al., 1994; Auger and De Vries, 2002]. Steroidal regulation of VT/VP neuronal activity might therefore be more widespread than is currently believed.

\section{Is Seasonal Stability in VT Anatomy an Adaptation to} Unpredictable Breeding Conditions?

Given that VT/VP cells of the BSTm and their projections are steroid-dependent in virtually every tetrapod that has been examined [Goodson and Bass, 2001; De Vries and Panzica, 2006], the hormonal insensitivity of VT anatomy in zebra finches is particularly noteworthy. In our study, we tested three alternate hypotheses regarding the adaptive significance of this anatomical stability: (1) The first hypothesis states that seasonal stability in VT anatomy might support long-term stability in the maintenance of pair bonds. Zebra finches and other estrildid species maintain very long-term or life-long pair bonds [Goodwin, 1982; Zann, 1994, 1996], and in this regard they stand out from all other species (to our knowledge) in which the steroid dependency of VT/VP system has been examined. Pair bonding in male prairie voles is dependent upon VP, and VP also supports social recognition processes that could be a component of pair bond maintenance [Lim and Young, 2006]. Hence, we might expect less seasonal variation in the strongly bonding estrildids. (2) Our second hypothesis states that seasonal stability is an adaptation to living in large groups yearround. This idea is suggested by the observation that VT circuitry of the BSTm-LS exhibits a variety of functional and anatomical features that are positively related to species-typical group size [Goodson et al., 2006; Goodson and Wang, 2006]. (3) Our final hypothesis is that yearround stability in VT anatomy is an adaptation to unpredictable environments and this stability allows the behavioral flexibility that is required for opportunistic breeding. The rationale for this hypothesis is elaborated upon in the previous section.

In order to test these alternate hypotheses, we examined four estrildid species in breeding and nonbreeding condition - the zebra finch, violet-eared waxbill, Angolan blue waxbill, and spice finch. All of these species are monogamous, exhibit long-term pair bonds, provide biparental care, inhabit semiarid and/or grassland scrub habitat, and breed opportunistically or semi-opportunistically in response to rainfall and/or subsequent grass growth [Skead, 1975; Sikdar et al., 1992; Zann, 1996; Morton, 2009]. Thus, if seasonal stability in VT anatomy supported year-round maintenance of pair bonds, then we would have expected all four species to be seasonally stable; however, the spice finch exhibited large seasonal variation in VT-ir cell number, with very few cells found in nonbreeding individuals. The seasonal variation in spice finches is also inconsistent with our hypothesis that stability is an adaptation to living in large groups yearround. This is because spice finches form the largest groups of any estrildid, and because violet-eared waxbills (that exhibit seasonal stability in VT anatomy) live in territorial male-female pairs year-round [Goodwin, 1982].

Our final hypothesis about opportunism might be correct, however, given that the spice finch tends to prefer more mesic environments and exhibits a rhythm of gonadal growth and regression that approximates the monsoon cycle, even when birds are held under constant lighting conditions [Chandola-Saklani et al., 2004]. This cyclicity might adjust the threshold for breeding responses to environmental stimuli, rather than regulating it, as spice finches are somewhat flexible breeders and known to breed opportunistically, albeit with distinct peaks after seasonal rains [Sikdar et al., 1992]. Despite a weak sensitivity to supernormal day lengths [Bentley et al., 2000], 
which appears to be associated with increased feeding durations rather than day length per se [Perfito et al., 2008], zebra finches are apparently devoid of endogenous seasonal rhythms, and our experience with captive individuals of the African waxbill species suggest the same [Goodson, unpubl. obs.]. Collections of Uraeginthus waxbills and other estrildids near the end of an extended dry season (in February 2001) showed that all individuals retained fully regressed gonads at a time of the year that is typically well within the breeding period for estrildids in the Kalahari Desert [Goodson and Mines, unpubl. obs.], which strongly suggests that these birds do not show endogenous cycles of gonadal growth and regression. Indeed, even under the physiologically benign conditions of captivity, waxbills do not exhibit gonadal recrudescence in the absence of stimulatory cues [Goodson, unpubl. obs.]. These combined observations therefore suggest that spice finches are more physiologically seasonal than are the other three species that we examined, and spice finches occupy habitats that are likely more predictable (diverse habitats of Indoasia as opposed to deserts of southern Africa and the Australian outback). It is therefore notable that of the four species examined, only spice finches exhibited the 'normal' tetrapod pattern of seasonally-dependent VT immunoreactivity.

What specific benefits might opportunistic species gain through the year-round maintenance of VT circuitry? Vasotocin increases aggressive behavior specifically in the context of mate competition [Goodson and Adkins-Regan, 1999; Goodson et al., 2004b, 2009a; Kabelik et al., 2009], and estrildids re-pair rapidly following loss of a partner [Goodwin, 1982; Zann, 1996]. Perhaps most important, however, is that endogenous VT is a potent modulator of nesting activity in both males and females, as shown in recent experiments using a $\mathrm{V}_{1 \mathrm{a}}$ antagonist in zebra finches [Klatt and Goodson, unpubl. obs.]. These findings are consistent with those in rodents, where parental behavior is likewise facilitated by VP [Wang and De Vries, 1993; Bosch and Neumann, 2008].

\section{Conclusions}

The present results indicate that opportunistically breeding finches have evolved an insensitivity to sex hormones within the VT circuitry of the BSTm and LS, such that this circuitry is anatomically stable year-round. Androgens nevertheless regulate VT neurons in opportunistic finches by modulating baseline activity rates, a characteristic that might also be present in seasonally breeding species. Finches that inhabit more seasonal environments show dramatic changes in VT-ir cell number across breeding and nonbreeding conditions, as do most other tetrapod vertebrates that have been examined.

\section{Acknowledgements}

We would like to thank L.C. Ayres and S.E. Schrock for help with image analysis, E.D. Ketterson and D.J. Whittaker for radioimmunoassay assistance, and two anonymous reviewers for comments on the manuscript. This research was funded by NIMH grant RO1 MH-0-62656 to J.L.G.

\section{References}

- Auger CJ, De Vries GJ (2002) Progestin receptor immunoreactivity within steroid-responsive vasopressin-immunoreactive cells in the male and female rat brain. J Neuroendocrinol 14:561-567.

Axelson JF, Leeuwen FW (1990) Differential localization of estrogen receptors in various vasopressin synthesizing nuclei of the rat brain. J Neuroendocrinol 2:209-216.

-Bentley GE, Spar BD, MacDougall-Shackleton SA, Hahn TP, Ball GF (2000) Photoperiodic regulation of the reproductive axis in male zebra finches, Taeniopygia guttata. Gen Comp Endocrinol 117:449-455.

-Bester-Meredith JK, Marler CA (2001) Vasopressin and aggression in cross-fostered California mice (Peromyscus californicus) and white-footed mice (Peromyscus leucopus). Horm Behav 40:51-64.
Bosch OJ, Neumann ID (2008) Brain vasopressin is an important regulator of maternal behavior independent of dams' trait anxiety. Proc Natl Acad Sci USA 105:17139-17144.

-Boyd SK (1994) Gonadal steroid modulation of vasotocin concentrations in the bullfrog brain. Neuroendocrinology 60:150-156.

Buijs RM, Pevet P, Masson Pevet M, Pool CW, De Vries GJ, Canguilhem B, Vivien-Roels B (1986) Seasonal variation in vasopressin innervation in the brain of the European hamster Cricetus cricetus. Brain Res 371:193-196.

Caldwell HK, Lee H, Macbeth AH, Young WS 3rd (2008) Vasopressin: Behavioral roles of an 'original' neuropeptide. Prog Neurobiol 84:1-24.

Carter CS, Grippo AJ, Pournajafi-Nazarloo H Ruscio MG, Porges SW (2008) Oxytocin, vasopressin and sociality. Prog Brain Res 170: 331-336.
-Chandola-Saklani A, Thapliyal A, Negi K, Diyundi SC, Choudhary B (2004) Daily increments of light hours near vernal equinox synchronize circannual testicular cycle of tropical spotted munia. Chronobiol Int 21: 553-569.

Chaturvedi CM, Prasad SK (1991) Timed daily injections of neurotransmitter precursors alter the gonad and body weights of spotted munia, Lonchura punctulata, maintained under short daily photoperiods. J Exp Zool 260:194-201.

Clayton NS (1990) Mate choice and pair formation in Timor and Australian mainland zebra finches. Anim Behav 39:474-480.

Crenshaw BJ, De Vries GJ, Yahr P (1992) Vasopressin innervation of sexually dimorphic structures of the gerbil forebrain under various hormonal conditions. J Comp Neurol 322:589-598. 
Cynx J (2001) Effects of humidity on reproductive behavior in male and female zebra finches (Taeniopygia guttata). J Comp Psychol 115:196-200.

De Vries GJ, Boyle PA (1998) Double duty for sex differences in the brain. Behav Brain Res 92: 205-213.

-De Vries GJ, Panzica GC (2006) Sexual differentiation of central vasopressin and vasotocin systems in vertebrates: different mechanisms, similar endpoints. Neuroscience 138: 947-955.

De Vries GJ, Buijs RM, Sluiter AA (1984) Gonadal hormone actions on the morphology of the vasopressinergic innervation of the adult rat brain. Brain Res 298:141-145.

De Vries GJ, Buijs RM, Van Leeuwen FW, Caffe AR, Swaab DF (1985) The vasopressinergic innervation of the brain in normal and castrated rats. J Comp Neurol 233:236-254.

-De Vries GJ, Duetz W, Buijs RM, Van Heerikhuize J, Vreeburg JTM (1986) Effects of androgens and estrogens on the vasopressin and oxytocin innervation of the adult rat brain. Brain Res 399:296-302.

-De Vries GJ, Wang Z, Bullock NA, Numan S (1994) Sex differences in the effects of testosterone and its metabolites on vasopressin messenger RNA levels in the bed nucleus of the stria terminalis of rats. J Neurosci 14: 1789-1794.

Donaldson ZR, Young LJ (2009) Oxytocin, vasopressin, and the neurogenetics of sociality. Science 322:900-904.

Dubois-Dauphin M, Theler JM, Ouarour A, Pevet P, Barberis C, Dreifuss JJ (1994) Regional differences in testosterone effects on vasopressin receptors and on vasopressin immunoreactivity in intact and castrated Siberian hamsters. Brain Res 638:267-276.

- Frazier CRM, Trainor BC, Cravens CJ, Whitney TK, Marler CA (2006) Paternal behavior influences development of aggression and vasopressin expression in male California mouse offspring. Horm Behav 50:699-707.

Goodson JL (2008) Nonapeptides and the evolutionary patterning of sociality. Prog Brain Res 170:3-15.

-Goodson JL, Adkins-Regan E (1999) Effect of intraseptal vasotocin and vasoactive intestinal polypeptide infusions on courtship song and aggression in the male zebra finch (Taeniopygia guttata). J Neuroendocrinol 11:19-25.

-Goodson JL, Bass AH (2001) Social behavior functions and related anatomical characteristics of vasotocin/vasopressin systems in vertebrates. Brain Res Brain Res Rev 35:246-265.

-Goodson JL, Evans AK (2004) Neural responses to territorial challenge and nonsocial stress in male song sparrows: segregation, integration, and modulation by a vasopressin $V_{1}$ antagonist. Horm Behav 46:371-381.

-Goodson JL, Kabelik D (2009) Dynamic limbic networks and social diversity in vertebrates: from neural context to neuromodulatory patterning. Front Neuroendocrinol 30:429441.
Goodson JL, Wang Y (2006) Valence-sensitive neurons exhibit divergent functional profiles in gregarious and asocial species. Proc Natl Acad Sci USA 103:17013-17017.

Goodson JL, Evans AK, Lindberg L (2004a) Chemoarchitectonic subdivisions of the songbird septum and a comparative overview of septum chemical anatomy in jawed vertebrates. J Comp Neurol 473:293-314.

Goodson JL, Evans AK, Lindberg L, Allen CD (2005b) Neuro-evolutionary patterning of sociality. Proc Biol Sci 272:227-235.

Goodson JL, Evans AK, Soma KK (2005a) Neural responses to aggressive challenge correlate with behavior in nonbreeding sparrows. Neuroreport 16:1719-1723.

Goodson JL, Evans AK, Wang Y (2006) Neuropeptide binding reflects convergent and divergent evolution in species-typical group sizes. Horm Behav 50:223-236.

Goodson JL, Kabelik D, Schrock SE (2009a) Dynamic neuromodulation of aggression by vasotocin: influence of social context and social phenotype in territorial songbirds. Biol Lett 5:554-556.

Goodson JL, Lindberg L, Johnson P (2004b) Effects of central vasotocin and mesotocin manipulations on social behavior in male and female zebra finches. Horm Behav 45:136143.

Goodson JL, Rinaldi J, Kelly AM (2009b) Vasotocin neurons in the bed nucleus of the stria terminalis preferentially process social information and exhibit properties that dichotomize courting and non-courting phenotypes. Horm Behav 55:197-202.

Goodwin D (1982) Estrildid Finches of the World. Ithaca, NY: Cornell University Press.

- Hahn TP, MacDougall-Shackleton SA (2008) Adaptive specialization, conditional plasticity and phylogenetic history in the reproductive cue response systems of birds. Philos Trans R Soc Lond B Biol Sci 363:267-286.

- Hahn TP, Watts HE, Cornelius JM, Brazeal KR, MacDougall-Shackleton SA (2009) Evolution of environmental cue response mechanisms: Adaptive variation in photorefractoriness. Gen Comp Endocrinol 163:193-200.

Immelmann K (1965) Australian finches in bush and aviary. Sydney and London: Angus and Robertson.

Kabelik D, Kelly AM, Goodson JL (2010) Dopaminergic regulation of mate competition aggression and aromatase-Fos colocalization in vasotocin neurons. Neuropharmacology 58:862-866.

Kabelik D, Klatt JD, Kingsbury MA, Goodson JL (2009) Endogenous vasotocin exerts context-dependent behavioral effects in a seminaturalistic colony environment. Horm Behav 56:101-107.

-Kabelik D, Weiss SL, Moore MC (2008) Arginine vasotocin (AVT) immunoreactivity relates to testosterone but not territorial aggression in the tree lizard, Urosaurus ornatus. Brain Behav Evol 72:283-294.
Kimura T, Okanoya K, Wada M (1999) Effect of testosterone on the distribution of vasotocin immunoreactivity in the brain of the zebra finch, Taeniopygia guttata castanotis. Life Sci 65:1663-1670.

Lakhdar-Ghazal N, Dubois Dauphin M, Hermes MLHJ, Buijs RM, Bengelloun WA, Pevet P (1995) Vasopressin in the brain of a desert hibernator, the Jerboa (Jaculus orientalis): Presence of sexual dimorphism and seasonal variation. J Comp Neurol 358:499-517.

- Lee DW, Fernando G, Peterson RS, Allen TA, Schlinger BA (2007) Estrogen mediation of injury-induced cell birth in neuroproliferative regions of the adult zebra finch brain. Dev Neurobiol 67:1107-1117.

Lim MM, Young LJ (2006) Neuropeptidergic regulation of affiliative behavior and social bonding in animals. Horm Behav 50:506517.

Marler CA, Bester-Meredith JK, Trainor BC (2003) Paternal behavior and aggression: Endocrine mechanisms and nongenomic transmission of behavior. In: Advances in the Study of Behavior (Slater PJB, Rosenblatt JS, Snowdon CT, Roper TJ, eds), vol 32, pp $263-$ 323. New York: Academic Press.

- Meddle SL, Foidart A, Wingfield JC, Ramenofskyand M, Balthazart J (1999) Effects of sexual interactions with a male on fos-like immunoreactivity in the female quail brain. J Neuroendocrinol 11:771-784.

- Miller MA, De Vries GJ, al-Shamma HA, Dorsa DM (1992) Decline of vasopressin immunoreactivity and mRNA levels in the bed nucleus of the stria terminalis following castration. J Neurosci 12:2881-2887.

- Miller MA, Urban JH, Dorsa DM (1989) Steroid dependency of vasopressin neurons in the bed nucleus of the stria terminalis by in situ hybridization. Endocrinology 125:2335-2340.

- Moore FL, Richardson C, Lowry CA (2000) Sexual dimorphism in numbers of vasotocinimmunoreactive neurons in brain areas associated with reproductive behaviors in the roughskin newt. Gen Comp Endocrinol 117: 281-298.

- Moore MC (1986) Elevated testosterone levels during nonbreeding-season territoriality in a fall-breeding lizard, Sceloporus jarrovi. J Comp Physiol A 158:159-163.

Morton S (2009) Rain and grass: lessons in how to be a zebra finch. In: Boom and Bust: Bird Stories for a Dry Country (Robin L, Heinsohn R, Joseph L, eds), pp 45-74. Collingwood, Victoria: CSIRO.

-Panzica GC, Aste N, Castagna C, Viglietti-Panzica C, Balthazart J (2001) Steroid-induced plasticity in the sexually dimorphic vasotocinergic innervation of the avian brain: behavioral implications. Brain Res Brain Res Rev 37:178-200.

- Perfito N, Kwong JM, Bentley GE, Hau M (2008) Cue hierarchies and testicular development: is food a more potent stimulus than day length in an opportunistic breeder (Taeniopygiag. guttata)? Horm Behav 53:567-572. 
-Perfito N, Zann RA, Bentley GE, Hau M (2007) Opportunism at work: habitat predictability affects reproductive readiness in free-living zebra finches. Funct Ecol 21:291-301.

-Plumari L, Plateroti S, Deviche P, Panzica GC (2004) Region-specific testosterone modulation of the vasotocin-immunoreactive system in male dark-eyed junco, Junco hyemalis. Brain Res 999:1-8.

Rasri K, Mason P, Govitrapong P, Pevet P, Klosen P (2008) Testosterone-driven seasonal regulation of vasopressin and galanin in the bed nucleus of the stria terminalis of the Djungarian hamster (Phodopus sungorus). Neuroscience 157:174-187.

-Scordalakes EM, Rissman EF (2004) Aggression and arginine vasopressin immunoreactivity regulation by androgen receptor and estrogen receptor alpha. Genes Brain Behav 3:2026.

-Sikdar M, Kar A, Prakash P (1992) Role of humidity in the seasonal reproduction of male spotted munia, Lonchura punctulata. J Exp Zool 264:82-84.

Skead DM (1975) Ecological studies of four estrildines in the central Transvaal. Ostrich (suppl)11:1-55.

-Small TW, Moore IT (2009) Seasonal neuroplasticity of the song control system in tropical, flexibly, and opportunistically breeding birds. Gen Comp Endocrinol 163:135-141.
Soma KK, Sullivan K, Wingfield J (1999) Combined aromatase inhibitor and antiandrogen treatment decreases territorial aggression in a wild songbird during the nonbreeding season. Gen Comp Endocrinol 115:442-453.

Szot P, Dorsa DM (1994) Expression of cytoplasmic and nuclear vasopressin RNA following castration and testosterone replacement: evidence for transcriptional regulation. $\mathrm{Mol}$ Cell Neurosci 5:1-10.

van Leeuwen FW, Caffe AR, De Vries GJ (1985) Vasopressin cells in the bed nucleus of the stria terminalis of the rat: sex differences and the influence of androgens. Brain Res 325: 391-394.

-Veenema AH, Neumann ID (2008) Central vasopressin and oxytocin release: regulation of complex social behaviours. Prog Brain Res 170:261-276.

Viglietti-Panzica C, Anselmetti GC, Balthazart J, Aste N, Panzica GC (1992) Vasotocinergic innervation of the septal region in the Japanese quail: sexual differences and the influence of testosterone. Cell Tissue Res 267:261265.

Viglietti-Panzica C, Balthazart J, Plumari L, Fratesi S, Absil P, Panzica GC (2001) Estradiol mediates effects of testosterone on vasotocin immunoreactivity in the adult quail brain. Horm Behav 40:445-461.

Voorhuis TA, de Kloet ER (1992) Immunoreactive vasotocin in the zebra finch brain (Taeniopygia guttata). Brain Res Dev Brain Res 69:1-10.
Voorhuis TAM, Kiss JZ, de Kloet ER, de Wied D (1988) Testosterone-sensitive vasotocin-immunoreactive cells and fibers in the canary brain. Brain Res 442:139-146.

-Wang Z, De Vries GJ (1993) Testosterone effects on paternal behavior and vasopressin immunoreactive projections in prairie voles $(\mathrm{Mi}$ crotus ochrogaster). Brain Res 631:156-160.

Wang Z, Smith W, Major DE, De Vries GJ (1994) Sex and species differences in the effects of cohabitation on vasopressin messenger RNA expression in the bed nucleus of the stria terminalis in prairie voles (Microtus ochrogaster) and meadow voles (Microtus pennsylvanicus). Brain Res 650:212-218.

Wingfield JC (2008) Organization of vertebrate annual cycles: implications for control mechanisms. Philos Trans R Soc Lond B Biol Sci 363:425-441.

Zann R (1994) Reproduction in a zebra finch colony in south-eastern Australia: the significance of monogamy, precocial breeding and multiple broods in a highly mobile species. Emu 94:285-299.

Zann RA (1996) The Zebra Finch: a synthesis of field and laboratory studies. Oxford, UK: Oxford University Press.

Zhou L, Blaustein JD, De Vries GJ (1994) Distribution of androgen receptor immunoreactivity in vasopressin- and oxytocin-immunoreactive neurons in the male rat brain. Endocrinology 134:2622-2627. 